\title{
Henrique Jales Ribeiro (Ed.): Rhetoric and Argumentation in the Beginning of the XXIst Century. Coimbra University Press, Coimbra, 2009, 312 pp
}

\author{
C. Andone
}

Published online: 19 August 2010

(C) The Author(s) 2010. This article is published with open access at Springerlink.com

This book is a trilingual collection of 18 articles (English, French, Portuguese) presented at a colloquium held at the University of Coimbra in Portugal (October $2-4,2008)$. The colloquium had two goals. One of the goals was to reflect on the impact to this day of two books that revolutionised the state of the art in argumentation in the XXth century: Perelman and Olbrechts-Tyteca's Traité de l'argumentation: La nouvelle rhétorique and Toumin's The Uses of Argument, both published in 1958. The other goal of the colloquium was "to take stock of the current state of rhetoric and argumentation theory." The present volume attests that especially the latter goal has been realized: it includes a survey of a variety of topics, and sometimes approaches, to the study of argumentation, written by some of the most prominent argumentation scholars.

The editor of the volume has chosen to divide the articles into five topical parts, each centred upon a different issue. I shall briefly discuss these articles in the order in which they are published, limiting myself to those in English and French. Unfortunately, the articles published in Portuguese can only be mentioned by the present reviewer without further comment.

Under the ambitious title Historical and philosophical studies on the influences of Perelman and Toulmin, two articles have been included in Part I. In the first article, J. Anthony Blair discusses The pertinence of Toulmin and Perelman/OlbrechtsTyteca for informal logic. Blair's article traces back the history of informal logic and attempts, often with caution, to show how Toulmin's and Perelman and Olbrechts-Tyteca's ideas have influenced the particular theoretical interests of informal logicians. Although informal logic came into being independently of the ideas of Toulmin and Perelman and Olbrechts-Tyteca, Blair claims a significant influence of the 1958 books on informal logic lately. In Blair's view, three of

C. Andone $(\bowtie)$

Department of Speech Communication, Argumentation Theory and Rhetoric,

Universiteit van Amsterdam, Spuistraat 134, 1012 VB Amsterdam, The Netherlands

e-mail: C.Andone@uva.nl 
Toulmin's concepts have particularly enriched informal logic. One of them is the concept of warrant seen as inference license, conferring relevance and embodying an argument scheme. Another concept influencing informal logic is the field or topic dependence of the backing. Finally, qualifiers and conditions of rebuttal "interpreted as signifying the defeasibility of arguments employed in much argumentation" (p. 17) have played an important role in the development of informal logic. Turning to Perelman and Olbrechts-Tyteca, the author acknowledges that their views regarding the context and the audience have touched upon the way in which argument analysis and evaluation have been conducted in informal logic in the last few years.

The second article included in Part I discusses the historical and philosophical merits of Perelman and Toulmin. Under the title Perelman and Toulmin as philosophers: On the inalienable connection between philosophy, rhetoric and argumentation, Henrique Jales Ribeiro claims that the works of Perelman and Toulmin are fundamentally "on and of rationality" and can be understood only in view of their "philosophical presuppositions and foundations" (p. 47). Ribeiro distinguishes between two opposite types of rationality at the basis of both works. On the one hand, the author refers to the existence of "scientific rationality," as in formal logic, which has led to the disappearance of rhetoric. On the other hand, Ribeiro distinguishes "an argumentative and critical rationality." The latter type of rationality is less clear: "[argumentative and critical rationality] will cover the wide spectrum of human action and man's superior interests in society, implying a temporal, open and contextual reason, of which a completely reformulated rhetoric, with new foundations, will be the model by excellence" (p. 48).

Part II, under the much too general title Studies in argumentation theory, begins with Frans H. van Eemeren's article on Strategic manoeuvring between rhetorical effectiveness and dialectical reasonableness. The article explains the recent pragma-dialectical framework for argument analysis and evaluation in which rhetorical insights are integrated into a dialectical framework. Strategic manoeuvring is a concept that is used to account for the arguers' efforts to reconcile an interest in maintaining dialectical standards of reasonableness with an interest for rhetorical effectiveness. The advantages gained from an integration of rhetorical with dialectical views are illustrated by van Eemeren in a discussion of fallacies. As a case in point, the author discusses arguments from authority and their fallacious realizations as argumentum ad verecundiam in informal discussions.

Using the same concept, A. Francisca Snoeck Henkemans deals with Praeteritio as strategic manoeuvring. She investigates the role that the figure of thought praeteritio may play in the arguers' attempts to reconcile their rhetorical with their dialectical aims in the different stages of a critical discussion. Apart from indicating possible dialectical and rhetorical effects which can be obtained by means of this figure, Snoeck Henkemans touches on the possible fallaciousness of moves involving praeteritio. The many examples in the article are a good illustration of the author's observations.

The next contribution to the volume is written by Douglas Walton and concerns Anticipating objections in argumentation. According to Walton, an argument that fits an argument scheme can be constructed into an argument that anticipates 
objections "by building an additional premise that anticipates the asking of a critical question matching the scheme at some future move" (p. 105). Starting from this complicated view, the author shows that a software system (Araucaria) can be used to visualize the argument scheme and argument structure of some kinds of refutations. Moreover, Walton claims that such a system is able to provide a way of anticipating typical critical questions matching an argument fitting one of the argument schemes. Walton's article is an illustration of a formal dialogue system that can be used as a method for constructing anticipating arguments. A demonstration of a good system for an appropriate argument analysis and evaluation is certainly still necessary, if only because the proposed method ignores the interactional aspect of an argumentative discussion and the fact that participants are interested in performing reasonable moves in their favour.

The fact that participants in an argumentative discussion are part of an exchange in which both parties cooperate but at the same time let their own arguments prevail, made Erik C. W. Krabbe write an article on Cooperation and competition in argumentative exchanges. The author wants to clarify how the trend to see argumentation as a common entreprise of two parties (cooperation) and the trend to see argumentation as a contest (competition) are to be understood. After tracing back the Platonic roots of the two trends and explaining how they fare in Aristotle, Krabbe reconstructs their positioning within the formal dialectical approaches and the pragma-dialectical approach. It is eventually argued that cooperation and competition need to be taken into account when constructing a normative model of argumentation. Krabbe proposes three ways in which this could be realized: (a) the cooperative and the competitive aspects could be assigned to different types of dialogue; (b) one of the aspects could be subordinated to the other, and (c) there could be a reconciliation of the two aspects in separate areas of one type of dialogue.

Part II comes to a close with Rui Alexandre Grácio's article Beyond argumentativeness: the unity of argumentation in which the author daringly proposes a new conceptualization of argumentation. Noticing that "the state of the art of the theories of argumentation shows that we are still in a pre-paradigmatic stage, characterized by greatly diverse and often incompatible approaches" (p. 127), Grácio proposes seeing argumentation not as "something that results from argumentativeness, but as something that produces argumentativeness" (Grácio's italics) (p. 127). Unfortunately how this proposal should be materialized needs further clarification. What to make of the following explanation: argumentation is "a kind of critical reading and interaction with discourses: it means reading discourses as thematization of issues that are inherently liable to perspectivation, detection of valued focal points and generation of a counter-discourse which problematizes them. Each one will know if and what for this kind of discipline will serve"? There is certainly some meaning in this remark, but this meaning is hard to reconstruct.

Part III, Linguistic approaches to argumentation theory, includes four papers of which three are in French. Oswald Ducrot's article Argumentation rhétorique et argumentation linguistique is a plea for changing the approach to argumentation from a rhetorical perspective (in which argumentation is seen as a means to bring a 
certain belief in the addressees) to a linguistic perspective (in which argumentation is made up of meaning-giving semantic atoms). Because of the complicated style in which the article is written, it is a hard task for the author to clarify how the change to a linguistic approach should be systematically made. Moreover, one may wonder how an argumentation analyst could account for context if argumentation is reduced to a purely linguistic approach.

In her article, Co-constructing the "reasonable" in verbal exchanges: theory of argumentation and discourse analysis, Ruth Amossy calls for a detailed analysis of argumentative exchanges in their context, suggesting that such an approach is fully in line with Perelman and Olbrechts-Tyteca. The author sees the ultimate goal of The New Rhetoric as giving an account of the discursive strategies through which people try to achieve some kind of consensus (the so-called verbal co-construction of the reasonable). In her view, a proper realization of this goal is possible through a close analysis of argumentative exchanges that starts from the available means theoretically distinguished by Perelman and Olbnrechts-Tyteca (for instance, the argument schemes) and is complemented by the empirical examination made possible by tools from discourse analysis.

Marianne Doury deals with Acte et personne dans l'argumentation: le cas $d u$ procès d'intention. More precisely, the author is concerned with accusations of 'procès d'intention', which according to Doury, are a sub-category of the circumstantial ad hominem attack consisting in "rejecting a claim or a line of action by bringing to light the bad intentions that could be used for defense" (p. 165, my translation). By taking a descriptive approach, Doury characterizes the linguistic form of such accusations in debates and the reactions to them, touching only superficially on the analysis and evaluation of the accusations. The analysis of the accusations of 'procès d'intention' needs to make clear which argumentative moves the accusations instantiate, the goals of such moves and the advantages an arguer gains from carrying them out. The evaluation of the accusations at issue lacks a set of criteria in accordance with which the moves could be judged as reasonable or unreasonable in the context of a debate.

The last contribution of Part III is written by Christian Plantin under the title Les éthè, leurs poids, et comment s'en débarrasser. The author has the ambition to clarify the notion of ethos in argumentation and to characterize it in a way that does justice to the multitude of facets of this notion. Starting from a brief lexicological analysis of ethos and other words from the same word family, Plantin wants to establish whether the research concerning this notion should be extended to "an ethics of discourse" (p. 182). What that means exactly remains an enigma. As the author explains, it would amount to answering the question: "quel est le rapport entre l'image qui est donneé du moi et l'image qui est donneé du surmoi dans le discours?" (p. 184, original italics). In an attempt to answer this question, Plantin discusses three dimensions of ethos: reputation, explicit discursive ethos and implicit discursive ethos, and proceeds to "the stylistic construction of the ethos" (p. 182). The author continues his complex theoretical approach by relating the study of ethos to Grize's theory of schematization. The article ends by making a connection between the place of ethos in rhetorical studies and in argumentation. This theoretical parcours does not offer a clear answer to the original question in 
which the author showed an interest in clarifying and characterizing the notion of ethos.

In Part IV, entitled Rhetoric and communication theory/Education theory approaches to the study of argumentation, apart from one article in English, all papers are written in Portuguese. I shall limit myself to mentioning their titles and the authors: Retórica da imagem? (Tito Cardoso e Cunha), Da retórica às indústrias da persuasão (António Fidalgo), A retórica-disciplina de comunicação: una e múltipla, na sociedale e na escola (José Nunes Esteves Rei), Se toda a argumentação é retórica, então toda a retórica deve ser oratória: Chaïm Perelman versus Olivier Reboul (Joaquim Neves Vicente). The paper in English is written by Alan G. Gross and concerns Solving the mystery of presence: verbal/visual interaction in Darwin's Structure and Distribution of Coral Reefs. Gross aims at furthering the analysis of Perelman and Olbrechts-Tyteca's concept of presence by providing a systematic account of the interaction of verbal and visual means. Although originally presence had been seen as "the product of verbal interaction alone" (p. 204), Gross is of the opinion that this cannot be true of all texts. In his view, in a text such as Darwin's The Structure and Distribution of Coral Reefs the images contribute significantly to meaning and therefore only an analysis of the interaction between words and images is suitable.

Finally, there are two articles published as Part V, Law theory approaches to argumentation. One of these articles is written by Hermenegildo Ferreira Borges under the title Nova retórica e democratização da justice, the other one by Guy Haarscher, Perelman, the use of the 'pseudo-argument' and human rights. The latter article deals with 'pseudo-argument,' which Haarscher defines, following Perelman and Olbrechts-Tyteca, as "an argument beginning with premises which the speaker does not really believe in" (p. 284). Haarscher provides a few examples from the legal field in order to show how such an argument works. He then analyses the examples and points out the various advantages an arguer may gain from advancing the described argument in order to gain approval.

As will be clear from this survey, Rhetoric and Argumentation in the Beginning of the XXIst Century is a collection of articles showing interests as varied as philosophical studies, historical approaches and linguistic matters, and more specific aspects of argumentative discourse such as counterarguments, fallacies and stylistic figures. This variety, and the fact that articles are published in English, French or Portuguese, makes the book potentially interesting to a wide audience. At the same time, the variety also has its disadvantages. For instance, the reader might find it difficult to move easily from one language to another, since the articles are thematically grouped instead of according to language. In addition, the thematic arrangement is not always really clear. What can a reader expect when he reads the title of Part II, Studies in argumentation theory, knowing already that he is dealing with a book on argumentation? Aren't all articles studies in the field of argumentation? Moreover, to prevent the reader from being disappointed, some of the titles of the various parts of the book could have been made more precise and more representative of the articles that fall under it. Take the title of Part I: Historical and philosophical studies on the influences of Perelman and of Toulmin. While the second article in this part deals indeed with the philosophical aspects in 
the works of the two scholars mentioned in the title, the first article by Blair has hardly any connection with the title of Part I. All in all, the book provides an illuminating view of certain recent studies in the field of argumentation and offers students interested in this area a useful but partial first introduction.

Open Access This article is distributed under the terms of the Creative Commons Attribution Noncommercial License which permits any noncommercial use, distribution, and reproduction in any medium, provided the original author(s) and source are credited. 